\title{
On the Right of Public Law EnTities to Lodge A CONSTITUTIONAL COMPLAINT IN THE LIGHT OF THE JuRisprudence OF THE POLISH CONSTITUTIONAL TRIBUNAL $^{1}$
}

\author{
MARTA KLOPOCKA-JASIŃSKA * \\ ADAM KRZYWON***
}

\section{INTRODUCTION}

In Polish scholarly literature the constitutional complaint is most often defined as a legal remedy available to individuals seeking to protect their constitutional rights against infringements by public authorities by means of a special procedure established before a constitutional court. ${ }^{2}$ This institution is not very common in the centralized model of constitutional judiciary. Nor can we speak of a uniform concept of the constitutional complaint existing in all the states in which it is used. However, it is often noted that in the states that have introduced the constitutional complaint procedure, particularly those employing a model affording a broad scope of protection, this introduction has changed the face of the constitutional court. ${ }^{3}$ In addition to its traditional safeguarding role, the institution of the constitutional complaint renders the constitutional court a guarantor of the freedoms and rights of the individual. In Poland we have also observed a positive effect of the

DOI: $10.1515 /$ wrlae-2015-0038

*Ph.D, assistant professor, Wyższa Szkoła Prawa im. Heleny Chodkowskiej, marta.klopocka-jasinska@prawowroclaw.edu.pl.

**Ph.D, assistant profesor, Uniwersytet Warszawski, adam.krzywon@gmail.com.

${ }^{1}$ This publication has been developed as part of the project financed by funds from the National Science Centre awarded under decision No. DEC-2013/11/D/HS5/01922.

2 Bogusław Banaszak, Józef Repel, 'Geneza skargi konstytucyjnej w Polsce' [The Origin of the Constitutional Complaint in Poland] in Janusz Trzciński (ed), Skarga konstytucyjna [Constitutional Complaint] (Wydawnictwo Sejmowe 2000) 33; Piotr Tuleja, Marian Grzybowski, 'Skarga konstytucyjna jako środek ochrony praw jednostki w polskim systemie prawa' [Constitutional Complaint as a Mean of Protection of Individual Rights in Polish Legal System] in Wiesław Skrzydło (ed), Sady i Trybunały w Konstytucji i praktyce [The Courts and Tribunals in the Constitution and in Practice] (Wydawnictwo Sejmowe 2005) 106.

${ }^{3}$ Cf Francisco Rubio Llorente, 'Seis tesis sobre la jurisdicción constitucional en Europa' (1992) 35 Revista Española de Derecho Constitucional 32; Germán Fernández Farreres, El recurso de amparo según la jurisprudencia constitucional (Marcial Pons 1994) 9; Marta Derlatka, Skarga konstytucyjna w Niemczech [Constituttional Complaint in Germany] (Wydawnictwo Sejmowe 2009) 6. 
constitutional complaint on the legal system; this measure has contributed to a better understanding of the constitutional catalogue of rights and freedoms.

The constitutional complaint entered the Polish legal system under the Constitution of the Republic of Poland of 2 April 1997 ("the Constitution"). The relevant constitutional provisions were subsequently completed by the Constitutional Tribunal Act of 1 August 1997. ${ }^{4}$ The institution of the constitutional complaint has been in existence in Poland for nearly two decades, and one might imagine that after this much time a matter of such practical importance as delineating the group of entities entitled to lodge a constitutional complaint should not cause any problems. However, quite the opposite is in fact the case, and the issue of standing to file a constitutional complaint remains unresolved. Many doubts exist around the issue of the admissibility of constitutional complaints brought by some entities, notably those with some connection to public authorities (sovereign capacity of the state). These doubts are a consequence of the ambiguous wording of Article 79(1) of the Constitution ${ }^{5}$, which provides for the right to lodge a constitutional complaint, and also the vagueness of the interpretation applied by the Constitutional Tribunal, although somewhat inconsistently. In Article 79(1) the legislator used a universal formula to delineate the group of persons entitled to file a complaint. It reads: "everyone whose constitutional freedoms or rights have been infringed". However, the notion of "everyone" has been defined neither in the Constitution nor in any statute, leaving room for a variety of interpretations. ${ }^{6}$

The imprecision of the above provision led to the Constitutional Tribunal developing its own criteria for assessing the capacity to file a constitutional complaint, that is, deciding who and in what circumstances has standing to do so. However, the criteria applied by the Constitutional Tribunal have not always been accepted in the scholarly literature, nor even among the judges of the Constitutional Tribunal. ${ }^{7}$ It is open for discussion whether a constitutional complaint may also be lodged by entities that the Tribunal refers to as public law entities, and thus considers to be linked with the state. In our opinion this issue takes on particular significance when it comes to commercial entities, units of local government and political parties. There are many arguments for granting them the right, at least partially, to initiate

\footnotetext{
${ }^{4}$ This act was amended by the Act on the Constitutional Tribunal of 25 June 2015 which was subsequently amended by the Act on the Constitutional Tribunal of 22 July 2016.

5 Art. 79 (1) of the Constitution of the Republic of Poland reads: "In accordance with principles specified by statute, everyone whose constitutional freedoms or rights have been infringed shall have the right to appeal to the Constitutional Tribunal for its judgment on the conformity to the Constitution of a statute or another normative act upon which basis a court or organ of public administration has made a final decision on his freedoms or rights or on his obligations specified in the Constitution."

6 Anna Łabno, 'Skarga konstytucyjna w III RP' [Constitutional Complaint in Republic of Poland] in Bogusław Banaszak, Artur Preisner (eds), Prawa i wolności obywatelskie RP [Rights and Civil Liberties in Poland] (C.H. Beck 2002) 772.

Cf Mirosław Wyrzykowski, Michał Ziółkowski, 'Konstytucyjny status proceduralny jednostki jako adresata działań organów administracji' [Constitutional Procedural Status of the Individual as the Recipient of Action by the Administration], in Roman Hauser, Zygmunt Niewiadomski, Andrzej Wróbel (eds), Konstytucyjne podstawy funkcjonowania administracji publicznej [Constitutional Basis for the Functioning of the Public Administration] (C.H. Beck 2012) 314.
} 
proceedings before the Constitutional Tribunal. In addition, the Constitutional Tribunal is still developing its line of judicial reasoning - it appears to have recently taken a slightly more relaxed approach in this regard, which may be a signal that the Tribunal hears and is responding to the concerns of the legal scholarly community.

\section{Personal Scope of the Constitutional Complaint in POLAND}

In order to discuss the standing to lodge a constitutional complaint enjoyed by certain categories of state-related entities (public business organizations, units of local government and political parties), general comments on the personal scope of this constitutional instrument should first be presented. As mentioned above, Art. 79(1) of the Constitution holds that the legal right to file a constitutional complaint rests with everyone "whose constitutional freedoms or rights have been infringed". Under this approach, the right to a complaint is available to all subjects of constitutional rights and freedoms.

It is thus clear that every citizen of Poland may make use of the instrument, as all Polish citizens are subjects of the rights and freedoms enumerated in Chapter II of the Constitution. However, the application of the expression "everyone" is broader, extending to other natural persons, including foreign nationals, subject to the wording of Article 79(2) of the Constitution and the exceptions established therein. ${ }^{8}$ This interpretation conforms with the general understanding of the rights and freedoms present in the Constitution according to which they are afforded to all people, subject only to a limited number of exceptions in which certain rights and freedoms are reserved only for citizens of Poland. In the above context, it should be emphasized that the constitutional complaint has been classified as one of the remedies against violations of the constitutional freedoms and rights that flow from human dignity (Art. 30 of the Constitution). This means that the rights resulting from dignity take precedence over laws passed by the state, and that the personal scope of the constitutional complaint should correspond to the broad constitutional protection of human dignity.

Legal scholars and jurisprudence in Poland have quite easily accepted the notion that the constitutional complaint may also be employed by juridical persons and unincorporated associations, to the extent that such entities may exercise constitutional freedoms and rights. This extension most obviously relates to property rights and freedom of economic activity - the legal rights that served as a basis for the development of the Constitutional Tribunal's jurisprudence which enabled juridical persons to lodge constitutional

\footnotetext{
${ }^{8}$ Pursuant to that provision, a constitutional complaint may not be used as a remedy against infringements of the rights set forth in Art. 56 of the Constitution of the Republic of Poland. Art. 56 provides foreign nationals with the right to asylum in Poland and enables them to apply for refugee status.
} 
complaints. ${ }^{9}$ Many arguments have been put forward in support of this approach. First and foremost, proponents of the extensive application of the constitutional complaint have called for a systemic and functional interpretation of Article 79 of the Constitution, which would allow for the function of procedural safeguard of constitutional freedoms and rights to be attributed to the constitutional complaint. Another important argument pertains to the personal scope of the freedoms and rights enshrined in instruments of international law, particularly in the European Convention for the Protection of Human Rights and Fundamental Freedoms. ${ }^{10}$

In the case of entities other than natural persons, the ability to successfully launch a constitutional review of legislation under the constitutional complaint procedure generally depends on complainants demonstrating that they are the subjects of a given freedom or right. The nature of a given entity and the manner in which its rights may be associated with human dignity are the crucial factors considered for the purpose of determining the foregoing. In consequence, this means that an entity without legal personality may also be afforded constitutional freedoms and rights.

Since the function of the constitutional complaint is to protect the rights and freedoms that derive from human dignity, bodies of public authority have been automatically excluded from the group of entities with standing to file a constitutional complaint. Such an interpretative approach to the issue taken by the Constitutional Tribunal has not led to any significant controversy. This is because public authorities have been made responsible for the effective enforcement of constitutional freedoms and rights. Moreover, these bodies have been given powers to authoritatively shape the legal position of private entities. In our opinion, the above approach is based on the correct assumption that it would be illogical for the constitution to oblige public authorities to respect freedoms and rights (under Art. 5 of the Constitution) ${ }^{11}$ and at the same time empower them to invoke these rights and freedoms in relations with other state bodies (Art. 37(1) of the Constitution). ${ }^{12}$ For these reasons, the Polish Constitutional Tribunal has held that any submission of a constitutional complaint by a public authority would be contrary to the essence of the instrument in question. ${ }^{13}$

However, in cases of bodies with some links to the state the straightforward assumption that public authorities have no standing to lodge a constitutional complaint was not enough to enable a clear-cut decision as to whether or not such bodies are legally capable of filing a complaint. Such organizations have been included in the dogmatic (and, unfortunately, not

${ }^{9}$ Cf judgment of the Constitutional Tribunal of 24 February 1999, Case No. SK 4/98; judgment of the Constitutional Tribunal of 8 June 1999, Case No. SK 12/98; decision of the Constitutional Tribunal of 21 March 2001, Case No. SK 6/99. All decisions of the Constitutional Tribunal cited in this paper are available at $<$ http://trybunal.gov.pl/>.

10 Sarah Joseph, 'Scope of Application' in Daniel Moeckli, Sangeeta Shah, Sandesh Sivakumaran (eds), International Human Rights Law (Oxford University Press 2010) 153.

${ }^{11}$ Article 5 of the Constitution provides, inter alia, that the Republic of Poland guarantees the freedoms and rights of persons and citizens.

${ }^{12}$ Under Art. 37(1) of the Constitution of the Republic of Poland any person who is under the authority of the Polish State may enjoy the freedoms and rights guaranteed by the Constitution.

${ }^{13}$ See e.g.: decisions of the Constitutional Tribunal of 2 November 2004 and 4 July 2005, Case No. Ts 163/04. 
uniform) class of "public law entities". The presence of links to the state - if noted at all by the Constitutional Tribunal ${ }^{14}$ - has repeatedly created confusion and led to a thorough evaluation of the structure and role of such an entity, its relations with the state and the influence of public authorities on its functioning. Many doubts have arisen in the course of the Tribunal's examination of constitutional complaints lodged by court enforcement officers, ${ }^{15}$ the professional association of notaries, ${ }^{16}$ political parties, ${ }^{17}$ entities discharging a public function, ${ }^{18}$ provincial governors (appointed by the central government), ${ }^{19}$ counties ("powiat" the intermediate level of local government), ${ }^{20}$ county-level organizational units, ${ }^{21}$ communes ("gmina", municipalities, the lowest level of the local government ${ }^{22}$ and municipalitylevel organizational units (such as a municipal utility operator). ${ }^{23}$ In general, it has been assumed that even a public law entity may lodge a constitutional complaint, provided that it is a beneficiary of the legal right invoked in the complaint. Such an interpretive approach leads to the conclusion that each individual case should be tested as to whether or not there is justification for a substantive review of the contention of unconstitutionality of a legal act because of the nature of a given constitutional freedom or right, or because of the link between a given entity (its individual members) and human dignity.

\footnotetext{
${ }^{14}$ See: judgment of the Constitutional Tribunal of 21 March 2005, Case No. SK 24/04. The complainant in this case was the Agricultural Property Agency, a state-owned corporation discharging public policy functions. In this case, the Tribunal accepted and examined the complaint lodged by the Agency, a body acting within the sovereign capacity of the state, and failed to make any comment on the Agency's standing to lodge a constitutional complaint in the statement of reasons appended to the judgment, which, considering the fact that public authorities had been already deemed deprived of such standing at the time, can only be explained as an omission on the part of the constitutional judges. A similar interpretation should be applied to the judgment of the Constitutional Tribunal of 28 January 2003, Case No. SK $37 / 01$, which was prompted by a constitutional complaint lodged by a singleshareholder company owned by the State Treasury. In this case, the Constitutional Tribunal altogether failed to review whether the legal right invoked in the complaint could have been exercised by the complainant. In holding the challenged legal provision unconstitutional because of a violation of the principle of citizens' trust in the state and the law (enshrined in Art. 2 of the Constitution), the Tribunal disregarded the fact that the complainant company conducted all its operations with the use of public property.

${ }^{15}$ See: judgments of the Constitutional Tribunal of: 20 January 2004, Case No. SK 26/03; 24 February 2009, Case No. SK 34/07; 30 April 2012, Case No. SK 4/10.

${ }^{16}$ See: decision of the Constitutional Tribunal of 21 October 2011, Case No. Ts 311/10.

${ }^{17}$ See: decision of the Constitutional Tribunal of 17 November 2010 and 15 September 2011 , Case No. Ts 256/09.

${ }^{18}$ See: judgments of the Constitutional Tribunal of: 2 June2010, Case No. SK 38/09 (the applicant was a research and development entity); 4 April 2005, Case No. SK 7/03 (the applicant was an Independent Public Healthcare Center).

${ }^{19}$ See: decision of the Constitutional Tribunal of 31 May 2005 and 11 January 2006, Case No. Ts $36 / 05$.

${ }^{20}$ See: decision of the Constitutional Tribunal of 3 October 2005 and 12 February 2006, Case No. Ts $148 / 05$.

${ }^{21}$ See: decisions of the Constitutional Tribunal of: 7 February 2012, Case No. Ts 192/11; 27

September 2005 and 7 December 2005, Case No. Ts 83/05.

${ }^{22}$ See in particular: judgment of the Constitutional Tribunal of 22 May 2007, Case No. SK $70 / 05$.

${ }^{23}$ See: decision of the Constitutional Tribunal of 21 April 2006, Case No. Ts 58/06.
} 
In our opinion, the greatest controversy has resulted from the Constitutional Tribunal's approach to the capacity to lodge constitutional complaints by public business organizations, units of local government and political parties. Therefore, as mentioned above, their ability to file a constitutional complaint will be further analysed in greater detail. However, we would like to begin by presenting two general arguments that should be taken into account when reviewing a given entity's capacity to lodge a constitutional complaint.

First, as already noted, the existing tendency to question the standing of public entities to lodge constitutional complaints results from the philosophy of human rights and the central position of human dignity within the constitutional system. On the other hand, the state is responsible for safeguarding rights and freedoms and creating conditions in which they can be freely exercised. Collective entities may benefit from constitutional protection if they show that safeguards of freedoms and rights are linked to the legal rights of their members, i.e. natural persons. In our opinion, such an approach leads to the question as to whether making dignity the central point of reference in fact means that we can pre-emptively question the subjectivity of any other entities that are not linked, or show only an indirect link, to dignity.

In principle, constitutional freedoms and rights are derived from dignity, which is evident from the language of Article 30 of the Constitution. However, there are different types of links between dignity and the ability to exercise individual freedoms and rights. ${ }^{24}$ Following trends in human rights development, the protection of human dignity requires above all the respect of the purely personal sphere. ${ }^{25}$ Accordingly, personal freedoms and rights are very tightly coupled with dignity, while political rights are as well, albeit somewhat less tightly, for in their case a decisive element required in recognizing their holder may also be the status of citizen. For secondgeneration rights, and especially economic rights and basic constitutional procedural guarantees, the human-centric approach seems to exert a lesser influence on the process of identifying beneficiaries of rights and freedoms. Obviously, this does not mean questioning dignity as the source of all freedoms and rights, as the protection of rights of juridical persons is, in general, secondary and limited in comparison to the protection of the rights of individuals. However, if it appears that collective entities - other than those equipped with attributes of state power and exercising sovereign authority can be parties to certain legal relations created by constitutional rules, for instance taking part in litigation or holding certain property rights, then we see no reason why they should not be made subjects of relevant freedoms and rights.

Secondly, it may reasonably be argued that any rules which are as general as those set forth in Chapter Two of the Constitution of the Republic of Poland should be interpreted dynamically. In consequence, we are skeptical of the tendency to petrify constitutional standards in defining the personal scope of constitutional freedoms and rights, especially considering

\footnotetext{
${ }^{24}$ See: judgment of the Constitutional Tribunal of 12 December 2005, Case No. K 32/04.

${ }^{25}$ Christopher McCrudden, 'Human Dignity and Judicial Interpretation of Human Rights' (2008) 19 (4) The European Journal of International Law 722.
} 
the emergence of new organizational forms in legal practice. In any case, the recognition of a collective entity's ability to invoke a given right or freedom does not occur at the expense of the protection afforded to natural persons. A focus on a more relaxed interpretation of the personal scope of certain freedoms and rights is well-aligned with the nature of constitutional norms and improves the translation of the values preferred by the constitutional lawmaker into concrete legal rules.

\section{The Capacity to Lodge Constitutional Complaints by Public Law Entities in Poland}

\section{a) Public economic entities}

The first group of entities whose standing to lodge a constitutional complaint causes certain doubts is that of public economic entities. These are juridical persons conducting commercial activity that entails relations with the state, of a property or functional nature, (e.g. state-owned companies).

Initially, the jurisprudence of the Polish Constitutional Tribunal revealed a fairly narrow approach to the issue of their standing to file a constitutional complaint. ${ }^{26}$ As a rule, the Tribunal denied them such standing. In considering complaints lodged by entities that carried out business using public property the Tribunal failed to thoroughly review their specific freedoms and rights, and did not examine in what way seeking the protection of these rights was a manifestation of the subjectivity (dignity) of persons forming such entities. In the discussed decisions of the Constitutional Tribunal much emphasis was placed on the legal nature of the complainant: the Tribunal held that the classification of the complainant as a public entity was sufficient argument for the inadmissibility of the complaint. Accordingly, in its approach the Tribunal made two assumptions. Firstly, it disregarded the so-called constitutional (or formal) criterion. The Tribunal paid no attention to the legal form of a given public economic entity (i.e. either a private-law form, such as commercial partnership or company, or a public law form, such as state enterprise, state agency or fund). Secondly, the Tribunal adopted substantive criteria of a property or functional nature. Similarly, proving that a business entity operates in the sovereign or proprietary capacity of the state was not a substantial proof of its standing to file a constitutional complaint. According to the Constitutional Tribunal, entities exercising public functions may operate in both these capacities, irrespective of the legal form they adopt, and this automatically determines their lack of capacity to file a constitutional complaint.

What is meant by the "property" criterion was the capital basis for conducting business. In the Constitutional Tribunal's opinion, the factor distinguishing the activities of public economic entities is that they are based on public property. The functional criterion, on the other hand, boils down to examining the direct or indirect dominating influence of public authorities on the activities of a given entity (e.g. controlling the majority of votes or the

\footnotetext{
${ }^{26}$ See: decisions of the Constitutional Tribunal of: 20 December 2007, Case No. SK 67/05; 8 April 2008, Case No. SK 80/06; 6 April 2011, Case No. SK 21/07.
} 
right to appoint officers of a given legal entity, known as the "golden share"). However, it is worth noting that failure to meet the property criterion and basing business activity on mixed property (e.g. the presence of private shareholders in companies) did not mean that a given entity was automatically excluded from the category of public economic entities. In the case of companies with a majority shareholding of the State Treasury or units of local government, the only consequence of the involvement of private shareholders was the increased importance of the functional criterion.

However, the Constitutional Tribunal has not been consistent in applying the above conditions of subjectivity of public enterprises. For instance, the Tribunal classified as a public economic entity a company whose operations were not based on public, but private, property. ${ }^{27}$ At the same time, another entity fell outside this category on the basis of the functional criterion (operating in a sector crucial for the state's security and the state's special influence on the activities of this entity), which - in the light of the discussed case law - determined its lack of capacity to file a constitutional complaint. ${ }^{28}$

The line of reasoning under discussion here has come in for criticism. ${ }^{29}$ The most serious reservations concern the fact that the analysis of the capacity of public economic entities to lodge a constitutional complaint was performed without consideration of the objectives that constitutional complaints are supposed to meet. The reported problems involved difficulties with the proper classification of mixed entities - operating on the basis of public and private property - and a lack of explicit regulations governing the effects of changes in shareholding occurring in the course of proceedings before the Tribunal. These arguments were the reasons why, in 2013, the Polish Tribunal made an explicit departure from its previous line of reasoning. ${ }^{30}$ In this decision the Tribunal departed from ruling on an entity's right to file a constitutional complaint solely on the basis of its inclusion within the category of public economic entities (and hence, from the application of the property and functional criteria) towards examining whether the complainant is a beneficiary of a specific freedom or constitutional right. This means that the Tribunal has unequivocally decided to shift the center of gravity from assessing the features of a complainant to establishing whether or not it has specific constitutional freedoms and rights.

In the light of such a change in approach, the examination of the admissibility of a constitutional complaint lodged by a public economic entity operating under an organizational and legal framework typical of private law boils down to answering the question of whether such an entity enjoys a freedom or right stipulated in the constitutional provision indicated by the public economic entity as a standard of control. There are no impediments to accepting the subjectivity of such an entity if it is in the same situation as natural and other juridical persons and the challenged legal enactment applies to it pursuant to the same conditions under which the provision could apply to such natural and other juridical persons. The only unacceptable thing, in respect of public economic entities, is the practice of challenging normative

\footnotetext{
${ }^{27}$ See: decision of the Constitutional Tribunal of 15 February 2012, Case No. Ts 37/11.

${ }^{28}$ See: decision of the Constitutional Tribunal of 9 July 2012, Case No. SK 19/10.

${ }^{29}$ Cf Wyrzykowski, Ziółkowski (n 7) 314.

${ }^{30}$ Decision of the Constitutional Tribunal of 18 December 2013, Case No. Ts 13/12.
} 
acts that shape the position of such entities vis-à-vis the state in a specific manner, unique to them, which could never be applied to natural or other juridical persons.

In our opinion the revised approach of the Polish Constitutional Tribunal to the capacity of private entities is the correct one. We must not lose sight of the fact that the state participates in economic life in various forms in order to realize diverse values. Specifying the scope of this participation, including the constitutional limits of public economic activity, is a separate issue which should not a priori affect the capacity of entities conducting actual commercial activity to lodge a constitutional complaint. In our view, it is thus necessary to prepare systemic interpretations of the essence of a constitutional complaint as a remedy available to an entity that has constitutionally protected rights. If the state wants to create entities that depending on their type and role - may exercise specific freedoms and rights, then it must be consistent and offer them procedural protection as well.

The current position of the Polish Constitutional Tribunal in this regard corresponds to the constitutional jurisprudence and doctrinal views presented in other European states. In Spain, where entities performing administrative functions are generally denied the capacity to lodge constitutional complaints, it has been argued that it is acceptable to invoke elements of the right to court resulting from Article 24 of the Spanish Constitution. ${ }^{31}$ Spanish constitutional jurisprudence, on the other hand, takes a position emphasizing the need to examine the purpose of granting the protection sought by a public entity. Whenever such an entity applies to the constitutional court for protection of its legitimate interests unrelated to the performance of administrative functions, it should be treated in the same way as other entities. ${ }^{32}$ This, for instance, enabled the Spanish constitutional court to consider complaints from public entities ${ }^{33}$, and a company wholly owned by autonomous communities of Spain ("Comunidades Autónomas"). In the case of complainants invoking the right to court - following the observation that such a company has the same status as other entities involved in court proceedings, the Tribunal admitted for merit-based consideration the charges raised in the complaint. ${ }^{34}$ A similar situation has occurred in Switzerland. The Swiss constitutional court has accepted that state-owned entities may invoke constitutional freedoms and rights, provided they operate in the domain of private law, carry out profit-seeking business activities as private entities do,

\footnotetext{
${ }^{31}$ Ángel Gómez Montoro, 'Titularidad de derechos fundamentales' in Cesar Aguado Renedo, Manuel Aragón Reyes (eds), Derechos fundamentales y su protección. Temas Básicos de Derecho Constitucional (Civitas 2011) 56.

32 See: judgments of the Spanish Constitutional Tribunal of: 15 November 2000, Case No. STC 273/2000; 26 July 2001, Case No. STC 175/2001; 15 September 2008, Case No. STC 164/2008. All decisions of the Spanish Constitutional Tribunal cited in this paper are available at $<\mathrm{http}: / / \mathrm{www}$. tribunalconstitucional.es $>$.

${ }^{33}$ This group includes the National Museum, public television, a public fund and the state agency responsible for social insurance - see: Gema Rosado Iglesias, La titularidad de derechos fundamentales por la persona jurídica (Tirant Lo Blanch 2004) 258.

${ }^{34}$ See: judgment of the Spanish Constitutional Tribunal of 30 January 2006, Case No. STC 2/2006.
} 
or compete with other organizations in the market. ${ }^{35}$ Their capacity to lodge a constitutional complaint has been accepted in case law, on the condition it is established that uniform laws affect their position to the same extent to which they affect the position of natural and other juridical persons. ${ }^{36}$

In addition, the views of the Polish Constitutional Tribunal appear to be consistent with German jurisprudence and doctrine. Of primary importance here is Article 19(3) of the Basic Law for the Federal Republic of Germany, or the German Constitution, which states that "the basic rights shall also apply to domestic artificial juridical persons to the extent that the nature of such rights permits". The universal understanding of this provision should take into account a fundamental assumption of the German Constitution human dignity and freedom. As a result, a collective subject acquires constitutional guarantees, if its structure and activity are connected with the exercise of individual freedom. ${ }^{37}$ This has led, among other things, to the recognition of subjectivity in the area of constitutional rights and freedoms of churches and tertiary education institutions. ${ }^{38}$

Although German doctrine is skeptical about the state's involvement in commercial activity which is not justified as being in the interests of the public, ${ }^{39}$ such a possibility is not challenged per se. ${ }^{40}$ It is noted that the principles governing such activity are similar to those applied by private enterprises - they are subject to private law and benchmarked against economic criteria. ${ }^{41}$ Consequently, an entity in which the state is only a shareholder and whose activities are not related to the performance of public tasks, but are based on the freedom to do business, may also seek the protection of its basic rights. It is necessary then to recognize the standing of such an entity because it is an entity operating on the market under the same conditions as private entities and subject to general state regulations. A stateowned company is a subject of constitutional freedoms and rights, and German doctrine has even attempted to compile a list of the leading companies that have standing to lodge a constitutional complaint in proceedings pending before the Federal Constitutional Tribunal. ${ }^{42}$

\section{b) Units of local government}

The group of entities that the Polish Constitutional Tribunal consistently denies standing to file a constitutional complaint are units of

\footnotetext{
35 Andreas Auer, Giorgio Malinverni, Michel Hottelier, Droit constitutionnel suisse (Stämpfli Verlag AG 2000) 335.

${ }^{36}$ See: judgments of the Federal Court of: 25 February 1994, BGE 120 la 95; 3 March 1999, BGE 1251173.

${ }^{37}$ Stefan Storr, Der Staat als Unternehmer (Mohr Steibeck 2001) $187 \mathrm{ff}$.

38 Wolfgang Rüfner, 'Grundrechtsadressaten' in Josef Isensee, Paul Kirchhof (eds), Handbuch des Staatsrechts, Allgemeine Grundrechtslehren (C.F. Müller 2011) 793 ff.

39 Josef Isensee, 'Staatsaufgaben' in Josef Isensee, Paul Kirchhof (eds), Handbuch des Staatsrechts, Aufgaben des Staates, (C.F. Müller 2006) $171 \mathrm{ff}$.

${ }^{40}$ Reinhold Zippelius, Thomas Würtenberger, Deutsches Staatsrecht (C.H. Beck 2005) 189 ff.

${ }^{41}$ Hartmut Maurer, Allgemeines Verwaltungsrecht (C.H. Beck 2006) 44.

${ }^{42}$ See: Thomas Würtenberger, Stephan Neidhardt, 'L'État actionnaire en Allemagne', (2007)

4 Revue française d'administration publique 595.
} 
local government (municipality, county, province). ${ }^{43}$ The issue of standing to file a constitutional complaint appears highly problematic, especially in the light of the solutions implemented by the Polish Constitution. Article 16(1) of the Constitution reads: "the inhabitants of the units of basic territorial division shall form a self-governing community in accordance with law". In Article 16(2) the Polish Constitution stipulates that local government participates in the exercise of public power and "the substantial part of public duties which local government is empowered to discharge by statute shall be done in its own name and under its own responsibility". Local government is discussed in chapter VII of the Polish Constitution. It specifies the legal status of units of local government by, inter alia, granting them legal personality, acknowledging their right of ownership and other property rights and ensuring judicial protection of their independence. Moreover, it regulates the performance by local government of "public tasks not reserved by the Constitution or statutes for the organs of other public authorities" (Art. 163). Pursuant to Article 166(1-2) of the Constitution, "public duties aimed at satisfying the needs of a self-governing community shall be performed by units of local government as their direct responsibility". However, the legislator may - "if the fundamental needs of the State so require" - "instruct units of local government to perform other public duties", known as "prescribed duties". In addition, Article 167 of the Polish Constitution stipulates that local government units should "be assured public funds adequate for the performance of the duties assigned to them".

From the point of view of the Constitution there should be no doubt that a unit of local government participates in the exercise of public power, performs public tasks and relies on public funding. On the other hand, the Constitution protects the independence of units of local government, including their right of ownership and other property rights, making them responsible for the performance of their own public duties. This, in turn, means that in performing such duties units of local government act as autonomous entities independent of central authorities, aimed at satisfying the basic needs of their local community. ${ }^{44}$

By refusing to proceed with complaints filed by units of local government, the Constitutional Tribunal assumes that a constitutional complaint is a legal remedy designed to protect rights and freedoms from infringements by public authorities, and a municipality (county, province) as an entity performing public duties has no such rights. ${ }^{45}$ In the recent case law

\footnotetext{
${ }^{43}$ E.g. in decisions of the Constitutional Tribunal of: 26 October 2001, Case No. Ts 72/01; 12 October 2004, Case No. Ts 35/04; 6 April 2005, Case No. SK 9/05; 3 October 2005 and 15 February 2006, Case No. Ts 148/05; 22 May 2007, Case No. SK 70/05 (decided in full composition); 15 December 2009, Case No. Ts 163/09; 8 July 2011, Case No. Ts 145/11; 23 January 2014, Case No. Ts 67/12; 28 November 2014, Case No. Ts 110/11.

${ }^{44}$ Kamil Sikora, Samodzielność gminy $w$ aspekcie oddziaływań nadzorczych [Independence of Municipalities in Terms of Supervisory Interactions] (Wyższa Szkoła Handlowa w Radomiu 2010) 15.

${ }^{45}$ However, it is worth noting that not all decisions in which the Constitutional Tribunal refused to proceed with a complaint filed by units of local government have been taken unanimously. Cf. The dissenting opinion of Constitutional Tribunal Judge Ewa Łętowska in the decision of 22 May 2007, Case No. SK 70/05 and remarks of Constitutional Tribunal Judge Sławomira Wronkowska-Jaśkiewicz included in the dissenting opinion dated 6 April
} 
the Tribunal has relied, among other things, on a systemic interpretation: the reasoning is based on the position of a given provision in the internal structure of the Constitution of the Republic of Poland (argumentum a rubrica). The Tribunal pointed out that the placement of Article 79 of the Constitution in Chapter II governing the freedoms, rights and obligations of persons and citizens means that the word "everyone" appearing in this article must be interpreted through the prism of a subjective scope of individual constitutional freedoms, rights and duties which apply in the first place to natural persons. The Tribunal has negated the possibility of recognizing local government bodies as beneficiaries of individual constitutional rights and freedoms, which makes it impossible to grant them the capacity to lodge a constitutional complaint. ${ }^{46}$ According to the Tribunal, the decisive argument here is the fact that the sphere of rights of units of local government is regulated outside of Chapter II of the Constitution ("The Freedoms, Rights and Obligations of Persons and Citizens").

In denying units of local government the standing to file constitutional complaints, the Tribunal has many times referred to the essence/role of the constitutional complaint. The Tribunal has emphasized that the constitutional complaint is a legal remedy designed to protect the constitutional rights and freedoms of the individual from infringements by public authorities. According to the Tribunal, the protective function of the remedy is practically fulfilled as part of the relation between a natural or juridical person and public authorities. ${ }^{47}$ Therefore, if the constitutional complaint is an instrument directed against actions or omissions by public administration bodies, it may not at the same time be a legal remedy available to such bodies. The Tribunal holds the view that the complaint is not meant to protect the rights of publiclaw entities, including units of local government, participating in the exercise of public power. Accordingly, entities that act in the role of a public authority are not entitled to file constitutional complaints, because naturally they are not recipients of legal rights resulting from individual constitutional rights, but rather recipients of obligations related to the exercise of rights of other entities. The Polish Tribunal has often emphasized that if units of local government were allowed to lodge constitutional complaints, this legal remedy would be "turned into an instrument for resolving disputes between individual bodies wielding public authority" ${ }^{48}$ In the Tribunal's opinion this would also lead to equating entities which may potentially interfere with constitutional rights and freedoms - but which are simultaneously obliged to safeguard these rights - with the carriers of these rights. ${ }^{49}$

Another reason for denial of protection under the constitutional complaint procedure to units of local government is the possibility that an "abstract constitutional review" may be commenced by constitutive organs of local government units. Pursuant to Article 191(1)(3) of the Constitution of

2011, Case No. SK 21/07, which, though not directly pertaining to the standing of units of local government to file constitutional complaints, but concerned that of a public economic entity, did contain, nevertheless, the judge's comments on this issue.

${ }^{46}$ See: decision of the Constitutional Tribunal of 22 May 2007, Case No. SK 70/05.

${ }^{47}$ See: decision of 27 September 2005, Case No. Ts 83/05.

${ }^{48}$ See: decision of 20 December 2007, Case No. SK 67/05.

${ }^{49}$ As in the decisions of the Constitutional Tribunal of: 26 October 2001, Case No. Ts 72/01; 22 May 2007, Case No. SK 70/05. 
the Republic of Poland, constitutive organs of units of local government municipality and county councils, as well as provincial legislative assemblies - may apply to the Constitutional Tribunal if the normative act in question relates to matters relevant to the scope of their activity (Art. 191(2) of the Constitution). As a result, through its constitutive organ a unit of local government may enforce a special remedy allowing such a unit to initiate the constitutional review procedure before the Constitutional Tribunal. Therefore, the Tribunal concluded that the admissibility of simultaneous access to the constitutional complaint procedure by units of local government could not only lead to the circumvention of conditions for making an application as laid down in Article 191(2) of the Constitution, but could also call into question the reason for the existence of the institution of the constitutional complaint. ${ }^{50}$

In Polish constitutional law doctrine the issue of granting the standing to lodge a constitutional complaint to units of local government does not seem to be settled, even though some scholars subscribe to the position of the Constitutional Tribunal, citing similar arguments. ${ }^{51}$ On the other hand, those who claim that units of local government should, in exceptional circumstances, have the standing to file a constitutional complaint note that under Article 79(1) of the Constitution of the Republic of Poland the right to appeal to the Constitutional Tribunal is available to everyone who may enjoy constitutional freedoms or rights. ${ }^{52}$ In our opinion this position merits attention and can be defended in light of the provisions of the Polish Constitution. What is, in fact, important for this reasoning - as stated by the Tribunal itself - is the nature of the specific right that may be attributed to a given entity and the possibility of its infringement by a public authority. It is thus assumed that a unit of local government may be a subject of some constitutional freedoms and rights. This will happen where such a unit acts in the state's proprietary capacity, namely, when it is in the same situation as other non-public legal entities. Hence, there is no justification for why it should be denied the same treatment as these entities. In this proprietary capacity, a unit of local government may be an owner (a subject of the right of ownership and other property rights) and act as a subject of civil law

\footnotetext{
${ }^{50}$ See decisions of: 21 April 2006, Case No. Ts 58/06; 22 May 2007, Case No. SK 70/05.

${ }^{51}$ For a categorical opinion on the capacity of local government units to invoke rights and freedoms set forth in Chapter II of the Constitution of the Republic of Poland see: Leszek Garlicki, 'Komentarz do art. 64 Konstytucji' [Commentary to art. 64 of the Constitution] in Leszek Garlicki (ed), Konstytucja Rzeczypospolitej Polskiej. Komentarz [Constitution of the Republic of Poland. Commentary] (Wydawnictwo Sejmowe 2003) 13. A similar opinion was expressed in Janusz Trzciński, 'Zakres podmiotowy i podstawa skargi konstytucyjnej' [Personal Scope of the Constitutional Complaint] in Janusz Trzciński (ed), Skarga konstytucyjna [Constitutional Complaint] (Wydawnictwo Sejmowe 2000) 53.

52 See e.g.: Bogusław Banaszak, 'Skarga konstytucyjna i jej znaczenie w zakresie ochrony praw podstawowych' [The Constitutional Complaint and its Importance in the Field of Protection of Fundamental Rights] in Leszek Wiśniewski (ed), Podstawowe prawa jednostki $i$ ich sadowa ochrona [Fundamental Individual Rights and its Judicial Protection] (Wydawnictwo Sejmowe 1997) 178; Zdzisław Czeszejko-Sochacki, 'Skarga konstytucyjna w prawie polskim' [Constitutional Complaint in Polish Legal System] (1998) 1 Przegląd Sejmowy 41.
} 
relations to which the principles of equality of the parties and of no subordination of one entity to another apply. In such instances the unit's rights should be protected before courts, including before the constitutional court.

It is also possible that the constitutional rights guaranteed to a unit of local government, or at least specified in an act of parliament, are infringed by a central authority. Would it not be reasonable in such cases to grant a unit of local government the capacity to file a constitutional complaint, considering its special status as a self-governing entity independent of government administration, operating to serve the best interests of its local inhabitants? It is difficult to agree with the view that admitting constitutional complaints filed by municipalities (or counties and provinces) would lead to the degeneration of the role of the constitutional complaint, since a unit of local government serves the local community (self-governing community), and any initiatives aimed at securing the interests of the local community will rather have the effect of strengthening the protection afforded to the latter.

At this point it is important to remember the reasoning behind the links between human dignity and individual constitutional rights and freedoms as discussed above. As noted, for second-generation rights, particularly economic rights and basic constitutional procedural guarantees, the humancentric approach seems to exert a lesser influence on the process of identifying the beneficiaries of rights and freedoms. These, in turn, are the type of constitutional guarantees most often invoked by units of local government that file constitutional complaints. Moreover, one should not overlook the fact that, pursuant to the provisions of the Polish Constitution quoted above, residents of units of the basic territorial division of the state form self-governing communities; when participating in the exercise of public power these communities perform a substantial part of public duties, in particular those satisfying the needs of a self-governing community. Consequently, it is the very Constitution of the Republic of Poland that recognizes the relationship between the protection of the rights of local government units and the protection of the rights of their inhabitants. Undoubtedly, the inability of local government units to rely on the instrument of constitutional complaint, and thus to discharge their public duties may, at times, involve the infringement of the constitutional rights and freedoms of a given self-governing community.

We believe that granting the standing to file a constitutional complaint to units of local government does not undermine the reasons for the existence of the abstract constitutional review of law that can be commenced under Article 191(1)(3) of the Constitution. Obviously, a point for consideration could be the existence of two procedures available to a unit of local government for appealing to the Constitutional Tribunal: applications and constitutional complaints. However, the Constitution does not expressly rule out such a possibility. Likewise, it may not be concluded that these are two identical legal institutions. ${ }^{53}$ We must remember that the application referred

53 Interesting remarks on the issue of the differences between an application and constitutional complaint filed by the constitutive organs of the units of local governments can be found in: Aleksandra Kustra, Legitymacja podmiotów publicznych do wniesienia skargi konstytucyjnej' [Legitimacy of Public Entities to Lodge a Constitutional Complaint] (2011) 2 Zagadnienia Sądownictwa Konstytucyjnego 90. The author observes that at first 
to in Article 191(1)(3) of the Constitution is limited - with regard to its content - to normative acts relating to matters relevant to the scope of activity of eligible entities, in this case constitutive organs of units of local government. Therefore, it is necessary to examine whether the said condition is satisfied on a case-by-case basis. This means that the interpretation of the passage "the normative act relating to matters relevant to the scope of their activity" is of utmost importance. However, the issue of possible models of review invoked as part of the procedure initiated by an application submitted by an organ of local government is also significant. ${ }^{54}$

\section{c) Political parties}

Serious doubts have been raised in respect of the standing of political parties to lodge constitutional complaints. ${ }^{55}$ The Constitutional Tribunal has laid down quite strict criteria applicable to political parties, which have effectively prevented them from seeking protection of rights and freedoms before that court. ${ }^{56}$ A political party (one represented in the Polish Parliament) lodged a constitutional complaint to the Constitutional Tribunal challenging electoral law mechanisms that govern the financing of campaigns and elections. The main thrust of the complaint was a challenge against the rule that provided for forfeiture of a political party's property in the event of a failure to comply with statutory regulations. The complainant party argued that the relevant act of parliament violated the constitutional right to the protection of ownership and other property rights.

However, the Constitutional Tribunal denied the political party's capacity to submit constitutional complaints. In justifying its decision, the Constitutional Tribunal relied on, among other things, the "special legal and constitutional status" of political parties, or to be more exact, their "public law status" or even "state-building function" and a "continual correlation" between political parties and the state. According to the Tribunal, political parties play a special social and constitutional role in a democratic lawgoverned state, and form an element of the state's political structure. A political party can operate in the Parliament and influence how deputies exercise their mandate, organize and manage parliamentary affairs, as well as take part in legislative processes and the supervision of the executive. This, in the Tribunal's opinion, imbues political parties with a public law status; a

\footnotetext{
sight the scope of content-based review may appear to be the same for both institutions, however "if we (...) find that by entering into civil-law relations a unit of local government separates itself from its public-law tasks and roles and 'goes beyond the scope of its activities' under Art. 191(2) of the Constitution, then we can note a certain difference in the subject matter appealed to the Constitutional Tribunal".

54 See: Kustra (n 53) 91. The author indicates that granting no capacity to lodge a constitutional complaint entails the conclusion on a lack of adequacy between all these models of review that guarantee legal rights at the constitutional level.

${ }^{55}$ See: Wojciech Brzozowski, 'Glosa do postanowienia Trybunału Konstytucyjnego z dnia 15 września 2011 r. (sygn. akt Ts 256/09)' [Commentary on Decision of Constitutional Tribunal of 15 September 2011, Case No. Ts 256/09] (2012) 2 Przegląd Sejmowy 182; Michał Bartoszewicz, 'Glosa do postanowienia Trybunału Konstytucyjnego z dnia 15 września 2011 r. (sygn. akt Ts 256/09)' [Commentary on Decision of Constitutional Tribunal of 15 September 2011, Case No. Ts 256/09] (2012) 2 Przegląd Sejmowy 192.

${ }^{56}$ Decisions of: 17 November 2010 and 15 September 2011, Case No. Ts 256/09.
} 
political party was defined by the Constitutional Tribunal as "a juridical person of a public nature, influencing public authorities or attempting to exercise such influence." The Tribunal also held that the status of political parties was defined by the provisions of Chapter One of the Constitution of the Republic of Poland, and hence falls outside the scope of Chapter Two, which, in turn, means that a political party cannot exercise the constitutional freedoms and rights afforded to an individual, let alone remedies against violations of such freedoms and rights. By refusing to acknowledge the applicant political party's ability to lodge a constitutional complaint, the Polish constitutional court followed the line of reasoning applied to units of local government: it invoked argumentation referring to the internal structure of the Constitution, but also pointed to the function of the constitutional complaint as a remedy against violations of constitutional freedoms and rights. As the Constitutional Tribunal emphasized, this function is "irreconcilable with the nature of a political party as a subject of public law, participating in (...) the exercise of public power." In the Tribunal's opinion, a political party, as a body whose operations influence public authorities (quite often by personnel appointments) and the constitutional structure of the state, does not have standing to lodge constitutional complaints in respect of any matters related to the party's public law functions.

Thus the Tribunal held in the discussed case that the complainant $-\mathrm{a}$ political party active in the Parliament - participated in the exercise of public power, and ruled that settlements of political parties' financing received from the public purse or the application of the penalty of property forfeiture for their violations of legal rules governing electoral fundraising fall within the purview of public law.

Surprisingly, the Tribunal also found that the absence of the capacity to lodge a constitutional complaint in matters related to public law does not preclude political parties from effectively initiating judicial review of a legal enactment, for instance under the abstract review procedure: a political party "may apply for a review of the conformity of legal provisions to the Constitution or a ratified international agreement (Art. 188 (1) and (2) of the Constitution); parliamentary parties may launch such a review through a group of MPs or Senators, while parties without parliamentary representation are entitled to apply for such a review by authorized bodies such as the Commissioner for Human Rights or the Prosecutor General." The foregoing seems to lead to the conclusion that the Polish constitutional court had rejected the capacity of political parties to lodge constitutional complaints. However, in its final remarks to the statements of reasons appended to the decision of 15 September 2011, the Constitutional Tribunal expressly noted that its stance should not be interpreted as depriving political parties of any ability to use the constitutional complaint procedure. Political parties may legally lodge such complaints, said the Tribunal, in matters where they do not act as public law bodies that discharge responsibilities imposed on them under Article 11(1) of the Constitution, ${ }^{57}$ but, rather, operate as private entities

${ }^{57}$ Art. 11 (1) of the Constitution of the Republic of Poland reads: "The Republic of Poland shall ensure freedom for the creation and functioning of political parties. Political parties shall be founded on the principles of voluntariness and upon the equality of Polish citizens, 
regulated by provisions of universally applicable laws which govern the legal situation of all persons. The Tribunal gave the example of how a constitutional complaint could be lodged by a political party acting in the capacity of an owner of real property, in an attempt to challenge the constitutionality of property laws that were a basis for a final decision that in the complainant's opinion - violated their right of ownership.

The approach of the Polish constitutional court presented above is inconsistent and incoherent. This has been noted both in legal scholarship ${ }^{58}$ and in the dissenting opinion to the discussed decision of the Constitutional Tribunal. ${ }^{59}$ It may indeed be reasonably argued that political parties had been incorrectly assumed to be classified as 'subjects of public law' or 'legal persons of public nature'. A political party may not be classified as a subject of public law merely because Article 11, which describes the status of political parties, is placed in Chapter One of the Polish Constitution, the section that sets out the principles of the constitutional system. Such an argument should be considered incorrect: if that were the case, similar treatment should be given to other entities, organizations or institutions with their status regulated by Chapter One, such as the press, trade unions, voluntary associations of citizens, foundations, war veterans and married couples.

Even though political parties are a qualified type of association with special significance for the entire mechanism of the exercise of power in a democratic law-governed state, we are of the opinion that there is a difference between influencing state policy or the exercise of public power by democratic methods (Art. 11 of the Constitution) and the very exercise or wielding of public power. ${ }^{60}$ Since political parties are not independent in influencing the development of public policy and exercising public power, any arguments that claim they can shape public policy or set general legal rules, organize and manage parliamentary work or oversee the executive are merely unjustified simplifications. ${ }^{61}$ The fact is that no provision of the Constitution of the Republic of Poland describes a political party as an entity vested with the authority to rule the state. It would be inappropriate to assume that every political party is capable of actually influencing the exercise of public power, even if it is represented in the Parliament.

On the other hand, only a few of the dozens of officially registered political parties enjoy the status of parliamentary parties. In consequence, we should strongly oppose the Constitutional Tribunal's stance that a political party can use the abstract constitutional review initiated by a group of 50 Deputies or 30 Senators (or, if a party is not represented in the Parliament, by the Commissioner for Human Rights or the Prosecutor General) to

and the purpose of these principles shall be to influence the formulation of the policy of the State by democratic means."

${ }^{58}$ See: Bartoszewicz (n 55) 196, Brzozowski (n 55) 184.

${ }^{59}$ See the dissenting opinion of Judge Stanisław Rymar in the decision of the Constitutional Tribunal of 15 September 2011, Case No. Ts 256/09.

${ }^{60}$ A note should also be made of Art. 6 of the Political Parties Act of 27 June 1997, which reads that "political parties may neither perform functions legally reserved for public authorities nor replace such authorities in the performance of their functions".

${ }^{61}$ Brzozowski (n 55) 188. 
compensate for having no standing to lodge a constitutional complaint. ${ }^{62}$ Such an approach immediately raises doubts as to whether a request for constitutional review submitted by a group of members of a pluralistic public authority body may replace the filing of a constitutional complaint by a political party as an entity with a separate identity. ${ }^{63}$ As indicated above, we think it would be inappropriate to limit the personal scope of the constitutional complaint with a view to its protective role. On the contrary, that very function should justify extension of the category of entities with the capacity to lodge a complaint and the application of such rules of interpretation that would facilitate the use of the principle in dubio pro accione (when in doubt, proceedings should be continued) during a review of the admissibility of legal remedies.

It is difficult to agree with the view of the Tribunal holding that a political party does not exercise the rights and freedoms guaranteed to private entities as set out in Chapter II. The Tribunal itself in other decisions has explicitly confirmed that collective entities such as political parties do benefit from certain rights and freedoms. ${ }^{64}$ It has also been indicated in constitutional law scholarship that a political party may be a subject of the constitutional right to associate, ${ }^{65}$ the right of ownership, ${ }^{66}$ and the freedom of the creation and functioning of political parties, as defined in Art. 11 of the Constitution. ${ }^{67}$ Similarly, one cannot ignore the guarantees given to a political party which comprise the constitutional right to a court, or the standards resulting from the principles of good legislation derived from the principle of a democratic law-governed state. Hence, if we assume that a political party may be a beneficiary of specific constitutional freedoms and rights, then consequently we should grant it the right to lodge a constitutional complaint designed to protect these freedoms and rights.

\footnotetext{
${ }^{62}$ In the statement of reasons for the decision the Tribunal offered no explanation as to the course of action that should be taken by a party which does not have the number of Deputies or Senators required to initiate a constitutional review before the Constitutional Tribunal, or in a situation where the Commissioner for Human Rights or the Prosecutor General refuse to apply for such a review.

${ }^{63}$ As in Brzozowski (n 55) 190.

${ }^{64}$ In the judgment of 8 June 1999, Case No. SK 12/98, the Tribunal observed that the "The Constitution states certain rights and freedoms of collective entities such as political parties or religious organizations. It appears evident that certain rights, such as the right of ownership or freedom to e.g. conduct business must - from the nature of the economic system - cover not only natural persons but also economic entities which are not natural persons". And in the judgment of 20 July 2011, Case No. K 9/11 the Tribunal held that "the subject of the freedom of speech expressed in Art. 54(1) of the Constitution may be both individuals (natural persons) and collective entities, including political parties and voting committees that are, after all, made up of natural persons and speak on their behalf'.

${ }^{65}$ Wojciech Sokolewicz, 'Komentarz do art. 58 Konstytucji' [Commentary to art. 58 of the Constitution] in Leszek Garlicki (ed), Konstytucja Rzeczypospolitej Polskiej. Komentarz [Constitution of the Republic of Poland. Commentary] (Wydawnictwo Sejmowe 2005) 30.

${ }^{66}$ See: Sylwia Jarosz-Żukowska, 'Prawo do własności - własność jako prawo podmiotowe' [Right to Property - the Property as a Personal Right] in Banaszak, Preisner (n 6) 276.

${ }^{67}$ Artur Ławniczak, Artur Preisner, 'Wolność zrzeszania się w partie polityczne' [Freedom of association in political parties] in Michał Jabłoński (ed), Realizacja $i$ ochrona konstytucyjnych wolności i praw jednostki w polskim porzadku prawnym [Realization and Protection of Constitutional Freedoms and Rights of Individuals in the Polish Legal System] (Wydawnictwo Uniwersytetu Wrocławskiego 2014) 341.
} 
A similar approach is presented in the case law of the European Court of Human Rights (ECtHR). It is evident from statements by the ECtHR that political parties are considered associations which, owing to their key role in the proper functioning of the democratic system, may benefit from the mechanisms for protection of rights and freedoms created under the Convention for the Protection of Human Rights and Fundamental Freedoms (ECHR). It is stated consistently in the case law of the European Court of Human Rights that political parties are crucial for democracy and that they benefit from the rights guaranteed under Articles 10 and 11 of the Convention. ${ }^{68}$ A political party treated as an association enjoys the protection provided by freedom of association, ${ }^{69}$ and may also be a subject of the right to the protection of property laid down in Article 1 of Protocol No. 1 to the ECHR. $^{70}$

In one of its rulings the Strasbourg Court found that, in case of any doubt, an analysis should be undertaken of the legal status of a given organizational unit, its licenses, the nature of the tasks it performs, the context of their performance, and the level of its independence from public authorities. $^{71}$ German legal scholarship on constitutional law presents a similar approach to this matter. Here it is assumed that political parties are private entities by their very nature. ${ }^{72}$. According to the Federal Constitutional Court of Germany, political parties are subjects of rights and freedoms and should be treated as state bodies only when it comes to the right to participate in political life (Art. 21 of the German Constitution). ${ }^{73}$

In the context of the above reasoning, the approach of the Polish Constitutional Tribunal to the capacity of political parties to lodge a constitutional complaint is mistaken. However, one should agree with the Tribunal that an important public interest exists in examining the legality of funding obtained by political parties. The basis for such inspection is expressed in the Constitution of the Republic of Poland itself, which in Article 11(2) stipulates that "the financing of political parties shall be open to public inspection." Nevertheless, we believe that the possibility of acquiring the right to grants and subsidies from the state budget by political parties, as well as statutory limitations on the financing of political parties or their property rights, do not stand in the way of granting them the right to a constitutional complaint. Such protection is desirable particularly in a situation where statutory orders or prohibitions violate the constitutional principle of

\footnotetext{
68 See: United Communist Party of Turkey and others v. Turkey, ECtHR Judgment (30 January 1998) Application No. 19392/92; Refah Partisi (The Welfare Party) v. Turkey, ECtHR Judgment (Grand Chamber) (13 February 2003), Applications No. 41340/98, 41342/98, 41343/98 and 41344/98; Republican Party of Russia v. Russia, ECtHR Judgment (12 April 2011) Application No. 12976/07.

${ }^{69}$ Refah Partisi (The Welfare Party) v. Turkey, ECtHR Judgment (Grand Chamber) (14 February 2006), Applications No. 41340/98, 41342/98, 41343/98 and 28793/02; Christian Democratic People's Party v. Moldova (no. 2), ECtHR Judgment (2 February 2010) Application No. 25196/04.

${ }^{70}$ See: Russian Conservative Party of Entrepreneurs and Others v. Russia, ECtHR Judgment (11 January 2007), Application No. 55066/00 and 55638/00.

${ }^{71}$ Radio France v. France, ECtHR Judgment (30 March 2004) Application No. 53984/00.

72 Rüfner (n 35) 786.

${ }^{73}$ BVerfGE 47, 198 (223); BVefGE 4, 27 (30); 24, 300 (329); 27, 10 (17).
} 
proportionality as laid down in Article 31(3) of the Constitution. In such cases a political party should have the possibility of initiating the procedure of review by the Constitutional Tribunal through lodging a constitutional complaint, all the more so when considering it is not entitled to do so under the abstract constitutional review procedure. We should not forget that a political party is a form of the civic right to associate voluntarily, and by means of which citizens may exercise their freedom to participate in the political life of the state.

\section{CONCLUSIONS}

The above analysis shows that the category of public law entities is not uniform. It comprises public economic entities, local government units, and political parties. All of these organizations realize different purposes and constitutional values. However, in all cases a systemic interpretation of the essence of the constitutional complaint understood as a remedy available to an entity enjoying constitutionally protected rights is necessary. If the state wants to create units that - depending on their type and role - may exercise specific rights and freedoms, then it must be consistent and offer them procedural protection as well. We therefore support a liberal approach to granting the capacity to lodge a constitutional complaint to the categories of entities mentioned above. The fact that they have certain links with the state should not a priori deprive them of the possibility of seeking protection of their rights and freedoms before the Constitutional Tribunal. 